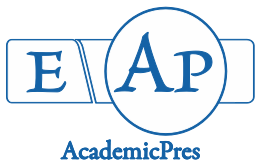

Njoga EO et al. (2020)

Notulae Scientia Biologicae 12(2):242-250

DOI: $10.15835 / \mathrm{nsb} 12210724$

Research Article

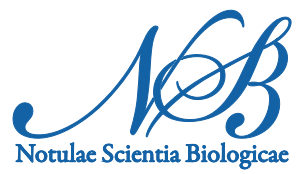

\title{
Surveillance for Campylobacter infections in indigenous poultry reared in Nsukka, Nigeria
}

\author{
Emmanuel O. NJOGA*, Ekene V. EZENDUKA, John A. NWANTA
}

University of Nigeria, Faculty of Veterinary Medicine, Department of Veterinary Public Health and Preventive Medicine, Nsukka; Enugu State, Nigeria; njoga.emmanuel@unn.edu.ng ( ${ }^{*}$ correspondingauthor); ekene.ezenduka@unn.edu.ng; johan.nwanta@unn.edu.ng

\begin{abstract}
Campylobacter is the leading cause of bacterial foodborne diseases worldwide. Poultry is indisputably the major reservoir of Campylobacter for human infection but dearth of data exists on the epidemiology of the infection in poultry in Nigeria. Consequently, the study determined the occurrence and distribution of Campylobacter infections and also the risk practices aiding the transmission in indigenous poultry reared in Nsukka, Nigeria. The bacteria isolation was done following standard microbiological protocol. The overall prevalence of the infection was $18.9 \%$. The specific prevalence was $19.6 \%$ and $17.8 \%$ in indigenous chicken and turkey respectively. In the chicken, frizzled feather and naked neck breeds had prevalence of $30.8 \%$ and $26.1 \%$ respectively while the normal feather breed had the lowest prevalence of $13.7 \%$. In both chicken and turkey, the infection was more during the wet season and in birds raised under extensive husbandry management. Major risk practices found were sale of untreated poultry faeces as organic fertilizer, eating during farm operations and non-use of protective clothing. The $18.9 \%$ prevalence is lower than $36 \%$ reported in 2010 but is very significant from food safety and public health perspectives. Considering the zoonotic and economic consequences associated with Campylobacter infection, adoption of farm-to-fork concept principles in indigenous poultry production in Nsukka is recommended, for further reduction or possible elimination of the infection. Proper treatment of poultry faeces before disposal or before use as feed (in fish or pig farms) or manure (in vegetable gardens) is important to curtail inter species transmission of Campylobacter in the study area.
\end{abstract}

Keywords: Campylobacter; food safety; indigenous poultry; local chicken; Nigeria; public health; risk practices

\section{Introduction}

Domestication of different species of poultry for meat or egg production is perhaps one of the oldest agribusinesses in human history. With an estimated poultry population of about 180 million as at 2015, producing 454 billion tons of poultry meat and 3.8 million eggs annually; Nigeria is the second largest producer of poultry in Africa (FAOSTAT, 2018). These data may have increased tremendously due to recent increase in poultry production activities in the country, particularly in the Southeast. The poultry subsector is the most commercialized agricultural subsector and has been adjudged the most dynamic and the fastest growing 
agribusiness in Nigeria; contributing about $10 \%$ of the agricultural gross domestic product (Heise et al., 2015; World Bank, 2017). Consequently, poultry production has significantly contributed to job creation, poverty alleviation, crime reduction and production of the much-needed animal protein in the country (Njoga et al., 2019).

The Nigerian indigenous poultry (NIP), made up of the Nigerian indigenous chicken (NIC) and Nigerian indigenous turkey (NIT) are members of the Gallus gallus domesticus. The species have continued to play crucial roles in the boom being experienced in the poultry subsector and in the economic wellbeing of the farmers. The NIC alone constitute about $60 \%$ of the poultry population in Nigeria and majority of these are reared under the extensive or scavenging free range production system in rural household (Yakubu et al., 2009; Ogie et al., 2013). With over 13 million Nigerian rural households involved in the production of NIP (World Bank, 2017), these poultry species have not only supported the economy of these families but have also augmented the supply of animal proteins, which unfortunately lags behind the supply in Nigeria (Ajibo et al., 2020), with over 203 million people.

Unfortunately, most avian species including the NIP are highly susceptible to Campylobacter infection, particularly $C$. jejuni and $C$. coli, popularly known as the thermophilic or thermotolerant species. Campylobacters are fastidious, spiral or rod-shaped Gram-negative bacteria infecting all warm-blooded animals. The organisms are flagellated (unipolar or bipolar) and are approximately 0.2 to 0.8 by 0.5 to $5 \mu \mathrm{m}$ in dimension (Kaakoush et al., 2015). Most Campylobacter species do not produce spores but grow under microaerophilic conditions ( $5 \% \mathrm{O} 2,10 \% \mathrm{CO} 2$ and $85 \% \mathrm{~N} 2$ ) at $42 \pm 1{ }^{\circ} \mathrm{C}$ (Nwankwo et al., 2016). Of the 28 validly described species and subspecies of Campylobacter, the thermophilic Campylobacter species (TCS) are the most important members of the genus (Modi et al., 2015), responsible for about $98 \%$ of all cases of campylobacteriosis in humans and animals (Gahamanyi et al., 2020).

The susceptibility of poultry to Campylobacter infection or colonization, more than other foodproducing animals (Sharp, 2016), may be due to the similitude in the temperature-growth requirement of the bacteria $\left(42 \pm 1^{\circ} \mathrm{C}\right)$ and that of the physiological temperature of the avian species $\left(42 \pm 1^{\circ} \mathrm{C}\right)$. As a result, poultry are the major reservoirs of Campylobacter organisms, for transmission to other food-producing animal or humans via the food chain (Sharp, 2016). The TCS, especially Campylobacter jejuni, are highly infective; such that just about 40 colony-forming unit (CFU) of the organism can produce disease in human and animal host (Newell and Fearnley, 2003).

Cases of foodborne illnesses due to Campylobacter in developed and developing countries have superseded that caused by classical enteric bacteria such as Salmonella and Escherichia coli (Facciola et al., 2017). Transmission of TCS proceeds essentially through the feco-oral route in both humans and animals. Globally, food safety concerns for transmission of zoonotic microbial pathogens via consumption of foods of animal origin have grown significantly in recent times, due to increased frequency of isolation of these pathogens in food-producing animals (Kaakoush et al., 2015). Humans usually acquired the infection via consumption of infected raw or undercooked foods of animal origin (Torralbo et al., 2014). Additionally, unhygienic food preparation practices, contamination of ready-to-eat foods, drinking of contaminated water and swimming in natural water bodies are major means of propagating Campylobacter infections in humans (Ugboma et al., 2013; Torralbo et al., 2014; Szczepanska et al., 2017).

Animal-human cohabitation, that still subsists in rural settings (Onunkwo et al., 2018), and none use of personal protective equipment (PPE) among occupationally exposed individuals (animal health workers, poultry farmers, live bird sellers and poultry carcass processors) exacerbate inter-species transmission of Campylobacter at the poultry-human interface (Ekere et al., 2018; Njoga et al., 2019). Moreover, the infection can still spread via contact with infected pet. In Denmark, Campylobacter jejuni was isolated from a woman living in the same household with an infected dog (Damborg et al., 2004). Evidence of the zoonotic 
transmission was further confirmed on detection of quinolone-resistance genes, with $\geq 95 \%$ similarity, from both the dog and human isolates (Damborg et al., 2004).

Immunologically naive or compromised individuals (pregnant women, the elderly, children less than 5 years, patients on immune suppressing drugs) are at higher risk of Campylobacter infection. Human campylobacteriosis is characterized by nausea, vomiting, diarrhea, dysentery, headache, fever, abdominal cramps and myalgia (Coker et al., 2003; Giwimi et al., 2015; Modi et al., 2015). These symptoms may develop 1-10 days post infection depending on the health and immune status of the individual. Although mortality rate associated with the human infection is low as some cases usually do not require antibiotic therapy (Hlashwayo et al., 2020), the organisms may cause severe health complications such as Guillain-Barré syndrome, reactive arthritis, irritable bowel syndrome and post-infectious polyneuropathy that may lead to paralysis (Ajene et al., 2013; Esan et al., 2017; Szczepanska et al., 2017).

In animals, Campylobacter infections rarely result in clinical disease in poultry but the infected birds remain sources of the infection to humans or other animals reared in the same environment. In ruminants however, Campylobacter causes infectious/septic abortions, infertility problems and other economically important health conditions (Sahin et al., 2017). Infection with C. jejuni caused massive abortions in sheep in the US and molecular evidence later proved that the infection was due to zoonotic transmission of an emergent highly pathogenic clone of the organism (Sahin et al., 2012).

In view of the zoonotic and economic importance of Campylobacter and the role of poultry in transmission of the infection, there is need for active surveillance for the infection especially in NIP reared in close proximity with humans and other food animals. Despite the importance, epidemiological data on the occurrence, distribution and transmission dynamics of TCS in NIP are sparse or where available far-between. Therefore, the study determined the occurrence and distribution of Campylobacter infections and also the risk practices aiding the transmission in indigenous poultry reared in Nsukka, Nigeria; to highlight the present status of the infection and recommend appropriate public health action.

\section{Materials and Methods}

\section{Study location, study design and data collection}

The demographics and geographical location of the study area, Nsukka agricultural zone, has been described (Abonyi and Njoga, 2020). Cross-sectional study design involving Campylobacter isolation from faecal samples and interview schedule was adopted in the study. A minimum sample size of 276 birds was calculated for the study, as described by Pourhoseingholi et al. (2013) based on 36\% prevalence reported by Akwuobu et al. (2010). However, for accuracy and buoyancy of data, a total of 316 faecal samples (209 from chicken and 107 from turkey) were randomly and aseptically collected for isolation of TCS. The faecal samples were collected directly from the cloacae, with the aid of a sterile swab sticks. For each sampled bird, the species, breed, sex, husbandry management system and season of the year were noted and recorded. Thereafter, the samples were transported in cold condition to the laboratory for the bacteria isolation. Interview schedule was used to obtain information on involvement of the poultry farmers in risk practices aiding Campylobacter infection and transmission.

\section{Isolation of thermophilic Campylobacter species}

The Campylobacter isolation was done using modified charcoal cefoperazone deoxycholate agar (MCCDA, CMO739, Oxoid, UK). The MCCDA was prepared according to the manufacturer's instruction and supplemented with a Campylobacter supplement (SRO 155E, Oxoid, UK) to aid the bacteria isolation. 
The swab samples were streaked directly on the supplemented agar and the set up incubated under microaerophilic conditions, generated by CampyGen ${ }^{\circ}$ (CN 0025A, Oxoid, UK) at $42{ }^{\circ} \mathrm{C}$ for $48-72$ hours.

In plates that yielded growth, the suspected bacteria colonies appearing flat, glossy and thinly spreading on the agar surface were purified on supplemented MCCDA under the same incubation conditions. Subsequently, putative pure colonies were subjected to biochemical characterization according to the methods of Barrett et al. (1988). Colonies that tested positive to biochemical characterization were Gram-stained and viewed under the oil-immersion objective. Presence of Gram-negative short rods or curved/spirally-shaped organisms were confirmatory.

\section{Statistical analyses}

Fishers' exact test was performed to check for significant statistical association $(p<0.05)$ between the bacteria infection and the poultry species and breeds. The same statistic was used to test for significant association $(\mathrm{p}<0.05)$ between TCI and epidemiological variables. The tests were performed at $5 \%$ probability level using GraphPad Prism ${ }^{\circ}$ version 6.04 (GraphPad ${ }^{\circ}$ Inc., San Diego, California, USA). Significance was accepted at $\mathrm{p}<0.05$.

\section{Results}

The overall prevalence of TCI in NIP was $18.9 \%$ (60/316). Specifically, the prevalence of the infection in NIC was $19.6 \%(41 / 209)$ while that of NIT was $17.8 \%(19 / 107)$ as shown in Table 1 . No statistical significance $(p>0.05)$ was noted between the bacteria infection and the poultry species even though the infection was slightly higher in the chicken than in the turkey (Table 1)

Results on the breed distribution of Campylobacter infections in indigenous chicken reared in Nsukka agricultural zone are presented in Table 2. The frizzled feather and naked neck breeds had prevalence of $30.8 \%$ and $26.1 \%$ respectively while the normal feather breed had the lowest prevalence of $13.7 \%$. Statistical significance $(\mathrm{p}<0.05)$ was found between the occurrence of the infection and the breeds (Table 2).

Similarly, findings on the distribution of Campylobacter infections in NIC and NIP according to various epidemiological variables are shown in Tables 3 and 4 respectively. In the NIC, there was preponderance of the infection during the wet (rainy) season (24.3\%) and in those raised under extensive management system $(28.4 \%)$. There was significant association $(\mathrm{p}<05)$ between TCI and husbandry management system but no significant association ( $p>0.05)$ existed between the infection and sex or season (Table 3).

In turkey, the infection also predominated during the wet season (20.7\%) and in extensively raised turkeys (23.7\%). However, no significant association ( $>0.05$ ) occurred between the infection and any of the epidemiological variables - sex, season and husbandry production system (Table 4).

Major risk practices aiding Campylobacter infection and spread in the farms/households surveyed were sale or use of untreated poultry faeces as organic fertilizer, eating during farm operations and non-use of PPE while on routine farm duties. In farms that practiced intensive husbandry system, risk practices found were non-treating or sanitization of drinking water, non-disinfection of feeding and drinking troughs and nonisolation of exposed birds or those returned unsold from the market.

Table 1. Prevalence of thermophilic Campylobacter infections in indigenous poultry $(n=316)$ reared in Nsukka, Nigeria

\begin{tabular}{|c|c|c|c|c|c|c|}
\hline $\begin{array}{c}\text { Poultry } \\
\text { species }\end{array}$ & $\begin{array}{c}\text { Number } \\
\text { tested }\end{array}$ & $\begin{array}{c}\text { Number } \\
\text { infected }\end{array}$ & Prevalence & $\begin{array}{c}\text { Odds } \\
\text { ratio }\end{array}$ & $95 \%$ CI & P-value \\
\hline Chicken & 209 & 41 & 19.6 & 1.1 & $0.62-2.2$ & 0.763 \\
\hline Turkey & 107 & 19 & 17.8 & & & \\
\hline
\end{tabular}




\begin{tabular}{|c|c|c|c|c|c|c|}
\hline Total & 316 & 60 & 18.9 & & & \\
\hline
\end{tabular}

Fishers' exact test, GraphPad Prism 6.04; CI = Confidence interval

Table 2. Breed distribution of Campylobacter infections in indigenous chicken $(n=209)$ reared in Nsukka, Nigeria

\begin{tabular}{|c|c|c|c|c|}
\hline Indigenous chicken breeds & Number tested & Number infected & Prevalence & P-value \\
\hline Naked neck & 46 & 12 & 26.1 & $0.029^{*}$ \\
\hline Fizzled feather & 39 & 12 & 30.8 & \\
\hline Normal feather & 124 & 17 & 13.7 & \\
\hline Total & 209 & 41 & 19.6 & \\
\hline
\end{tabular}

${ }^{*}$ Denotes statistical significance, Fishers' exact test, GraphPad Prism 6.04

Table 3. Distribution of Campylobacter infections in Nigerian indigenous chicken $(\mathrm{N}=209)$ according to various epidemiological variables

\begin{tabular}{|c|c|c|c|c|c|c|}
\hline $\begin{array}{c}\text { Epidemiological } \\
\text { variables }\end{array}$ & $\begin{array}{c}\text { Number } \\
\text { tested }\end{array}$ & $\begin{array}{l}\text { Number } \\
\text { infected }\end{array}$ & Prevalence & $\begin{array}{l}\text { Odds } \\
\text { ratio }\end{array}$ & $95 \% \mathrm{CI}$ & P-value \\
\hline \multicolumn{7}{|c|}{ SEX } \\
\hline Male & 73 & 14 & 19.1 & 0.96 & $0.47-2.1$ & 0.998 \\
\hline Female & 136 & 27 & 19.9 & & & \\
\hline \multicolumn{7}{|c|}{ SEASON } \\
\hline Wet & 107 & 26 & 24.3 & 1.9 & $0.27-1.1$ & 0.085 \\
\hline Dry & 102 & 15 & 14.7 & & & \\
\hline \multicolumn{7}{|c|}{ HUSBANDRY } \\
\hline Extensive & 88 & 25 & 28.4 & 2.6 & $0.19-0.77$ & $0.008^{*}$ \\
\hline Intensive & 121 & 16 & 13.2 & & & \\
\hline
\end{tabular}

${ }^{*}$ Denotes statistical significance, Fishers' exact test, GraphPad Prism 6.04; CI = Confidence interval

Table 4. Distribution of Campylobacter infections in Nigerian indigenous turkey $(n=107)$ according to various epidemiological variables

\begin{tabular}{|c|c|c|c|c|c|c|}
\hline $\begin{array}{c}\text { Epidemiological } \\
\text { variables }\end{array}$ & $\begin{array}{c}\text { Number } \\
\text { tested }\end{array}$ & $\begin{array}{l}\text { Number } \\
\text { infected }\end{array}$ & Prevalence & $\begin{array}{l}\text { Odds } \\
\text { ratio }\end{array}$ & $95 \% \mathrm{CI}$ & P-value \\
\hline \multicolumn{7}{|c|}{ SEX } \\
\hline Male & 44 & 8 & 18.2 & 1.1 & $0.39-2.9$ & 0.996 \\
\hline Female & 63 & 11 & 17.5 & & & \\
\hline \multicolumn{7}{|c|}{ SEASON } \\
\hline Wet & 58 & 12 & 20.7 & 0.64 & $0.28-1.5$ & 0.393 \\
\hline Dry & 49 & 7 & 14.3 & & & \\
\hline \multicolumn{7}{|c|}{ HUSBANDRY } \\
\hline Extensive & 38 & 9 & 23.7 & 1.8 & $0.67-5.0$ & 0.298 \\
\hline Intensive & 69 & 10 & 14.5 & & & \\
\hline
\end{tabular}

Fishers' exact test, GraphPad Prism 6.04; CI = Confidence interval

\section{Discussion}

The overall prevalence of $18.9 \%$ as well as the specific prevalence of $19.6 \%$ and $17.8 \%$ recorded for indigenous chicken and turkey respectively are lower than $36 \%$ reported in the same study area by Akwuoba $e t$ al. (2010). This is a clear indication that Campylobacter infection in indigenous poultry is decreasing in Nsukka, Nigeria. The decline may be due to intensive husbandry system of poultry production adopted in some farms surveyed. Being research farms, some of these farms practiced intensive husbandry system which may have reduced microbial infections in the animals. This husbandry system may have also limited exposure of the birds 
to harsh climatic conditions which facilitate infection with pathogens, especially in the tropics (Njoga et al., 2018). The husbandry system also limits incursion of wild or migratory birds, which are known natural reservoirs of pathogenic Campylobacter species (Dasti et al., 2010; Szczepanska et al., 2017), hence the low prevalence.

Moreover, prophylactic administration of antimicrobial agents widely practiced in poultry farms nationwide (Njoga et al., 2018) may have also contributed to the reduction in Campylobacter infection. Although TCI do not usually result in clinical disease in poultry, prophylactic administration of antimicrobial agents for management of other economically important bacterial diseases may have depopulated even the nontargeted organisms such as Campylobacter. The resultant effect therefore may have been decrease in Campylobacter colonization of poultry and thus the low prevalence being reported.

The overall and species-specific prevalence found in this work are also lower than $38.8 \%$ reported in indigenous chicken in Sokoto State, Northwest Nigeria (Salihu et al., 2009). The dissimilarities in the findings could be attributed to dichotomies in environmental, epidemiological or climatic factors at the study locations, which may have influenced the research outcomes. These factors include husbandry management systems, seasons of the year, health status of the birds and discrepancies in researchers' expertise in Campylobacter isolation and characterization.

Although the $18.9 \%$ prevalence being reported has been adjudged low, the prevalence of the infection was not expected to be that much considering the unique resilience and resistance of NIP to microbial infections (Ogie et al., 2013). The infection was this much probably due to poor biosecurity practices and the scavenging feeding habits of indigenous poultry, especially those reared under extensive production system. These afford poultry unrestricted access to wild and migratory birds which are natural reservoirs of Campylobacter (Dasti et al., 2010).

The $19.6 \%$ and $17.8 \%$ prevalence reported for indigenous chicken and turkey respectively may be lower than earlier reports (Salihu et al., 2009; Akwuobu et al., 2010; Nwankwo et al., 2016) but they are very significant from food safety and public health perspectives. Infection of one in every five-chicken surveyed (i.e. 19.6\%) portents great public health risk in the study area due to variety of reasons. Many people are engaged in poultry production in Nigeria and majority of these people do not use PPE during routine duties (Njoga et al., 2019). Poultry and poultry products enjoy wide acceptance across diverse ethnic backgrounds and religious beliefs. For instance, people relish poultry eggs (as the cheapest source of animal protein with $100 \%$ biological value) and chicken due to its low cholesterol content. Moreover, the NIC are usually reared organically such that the products contain no or little antimicrobial drug residues. These reasons make the risk of the human infection via the food chain very high.

Considering the role of poultry and poultry products in human campylobacteriosis (Sharp, 2016) and the ease of contamination of poultry meats during the carcass processing; human Campylobacter infection could become a public health emergency in the study area. However, the health emergency may not arise easily as most Africans have the culture of proper meat cooking in which meats are cooked (boiled, fried or grilled) at temperature range of 60 to $90^{\circ} \mathrm{C}$ for about 30 minutes (Okoli et al., 2018). This type of cooking ensures that most meat bacterial contaminants are killed-off or inactivated, thereby limiting the chances of the transmission through the food chain.

Beyond the human health problems, a major significance of the findings of this work is that the $19.6 \%$ infected chicken could serve as reservoirs of Campylobacter for infection of other food animals; especially small ruminants usually raised in close proximity with poultry. Abortion storms and other devastating disease conditions in ruminants due to Campylobacter infection has been reported (Sahin et al., 2012; 2017). There is also the possibility of contaminating drinking water sources with these enteric pathogens during disposal of poultry offal's or wastes from infected chicken; since slaughterhouse wastes or effluents are usually washed into natural water bodies during the rainy season (Njoga et al., 2019). Campylobacter organisms have been isolated 
in ground water (Ugboma et al., 2013). Drinking of such contaminated water has been associated with onset of diarrhea, especially in children.

Apart from aiding the contamination of natural water bodies which sometimes are sources of drinking water in rural settings, the role of rain and rainy (wet) season in the epidemiology of Campylobacter infection may be significant. It seems that moisture conditions associated with rainy season facilitates Campylobacter survival and transmission. This probably explains the preponderance of the infection during the rainy season in both the chicken and turkey species as found in this work. The seasonality in the infection as found in this research is in tandem with the findings of other researchers outside the study area (Nwankwo et al., 2018; Djennad et al., 2019) and this finding could be exploited in the control of the infection.

\section{Conclusions}

Since poultry is the major source of human Campylobacter infection and human health is complicatedly connected to that of animals, effort towards further reduction or possible elimination of Campylobacter infection in poultry is worthwhile. Good farm management practices and adoption of farm-to-fork concept of food safety in production of NIP in Nsukka are crucial in this regard. Proper treatment of poultry faeces before disposal or use as feed (in pig and fish farms) or manure (in vegetable and fruit gardens), are advocated to further reduce the transmission of Campylobacter and the associated health and economic problems.

\section{Acknowledgements}

This research was funded by the Tertiary Education Trust Fund (TETFund) of the University of Nigeria, Nsukka; under the Needs Assessment Intervention Fund for Academic Staff Training and Development.

\section{Conflict of Interests}

The authors declare that there are no conflicts of interest related to this article.

\section{References}

Abonyi FO, Njoga EO (2020). Prevalence and determinants of gastrointestinal parasite infection in intensively managed pigs in Nsukka agricultural zone, Southeast, Nigeria. Journal of Parasitic Diseases 44:31-39.

Ajene AN, Fischer-Walker CL, Black RE (2013). Enteric pathogens and reactive arthritis: a systematic review of Campylobacter, Salmonella and Shigella-associated reactive arthritis. Journal of Health Population and Nutrition 31:299-307.

Ajibo FE, Njoga EO, Azor N, Idika KI, Nwanta JA (2020). Epidemiology of infections with zoonotic pig parasites in Enugu State, Nigeria. Veterinary Parasitology: Regional Studies and Reports 20: 100397. https://doiorg/101016/juprsr2020100397

Akwuobu CA, Oboegbulem SI, Ofukwu RA (2010). Characterization and antibiogram of local isolates of Campylobacter species from chicken in Nsukka Area, Southeast Nigeria. American-Eurasian Journal of Sustainable Agriculture 4:117-121.

Barrett TJ, Patton CM, Morris GK (1998). Differentiation of Campylobacter species using phenotypic characterization. Journal of Laboratory and Medicine 19:96-102. 
Coker AO, Isokpehi RD, Thomas BN, Amisu KO, Obi CL (2002). Human campylobacteriosis in developing countries. Emerging infectious Diseases 8:237-244.

Damborg P, Olsen KEP, Nielsen EM, Guardabassi L (2004). Occurrence of Campylobacter jejuni in pets living with human patients infected with C jejuni. Journal of Clinical Microbiology 42:1363-1364.

Dasti JI, Tareen AM, Lugert R, Zautner AE, Gross U (2010). Campylobacter jejuni: A brief overview on pathogenicityassociated factors and disease-mediating mechanism International Journal of Medical Microbiology 300:205-211

Djennad A, Lo-Iacono G, Sarran C, et al (2019). Seasonality and the effects of weather on Campylobacter infections. BMC Infectious Diseases 19:225. https://doiorg/101186/s12879-019-3840-7

Ekere SO, Njoga EO, Onunkwo JI, Njoga UJ (2018). Sero-surveillance of Brucella antibody in food animals and role of slaughterhouse workers in spread of Brucella infection in Southeast Nigeria. Veterinary World 11:1171-1178.

Esan OB, Pearce M, Van-Hecke O, Roberts N, Collins DRJ, Violato M, ... Fanshawe TR (2017). Factors associated with sequelae of Campylobacter and non-typhoidal Salmonella infections: a systematic review EBio Medicine 15:100111.

Facciolà A, Riso R, Avventuroso E, Visalli G, Delia SA, Laganà P (2017). Campylobacter: from microbiology to prevention. Journal of Preventive Medicine and Hygiene 58: E79-E92.

FAOSTAT (2018). Food and Agricultural Organization of the United Nations. Retrieved at January 21, 2019 from wwwfaoorg/faostat/en/\#data/QA.

Gahamanyi N, Mboera LEG, Matee MI, Mutangana D, Komba EVG (2020). Prevalence risk factors and antimicrobial resistance profiles of thermophilic Campylobacter species in humans and animals in Sub-Saharan Africa: A systematic review. International Journal of Microbiology 2092478. https://doiorg/101155/2020/2092478

Gwimi PB, Faleke OO, Salihu MD, Magaji AA, Abubakar MB, Nwankwo IO, Ibitoye EB (2015). Prevalence of Campylobacter species in faecal samples of pigs and humans from Zuru Kebbi State, Nigeria. International Journal of One Health 1:1-5.

Heise H, Crisan A, Theuvsen L (2015). The poultry market in Nigeria: market structures and potential for investment in the market. International Food and Agribusiness Management Review 18:197-222.

Hlashwayo DF, Sigaugue B, Bila CG (2020). Epidemiology and antimicrobial resistance of Campylobacter spp. in animals in Sub-Saharan Africa. A systematic review. Heliyon 6:e03537.https://doi.org/10.1016/j.heliyon.2020.e03537

Kaakoush NO, Castaño-Rodríguez N, Mitchell HM, Man SM (2015). Global epidemiology of Campylobacter infection. Clinical Microbiology Reviews 28:687-720.

Modi S, Brahmbhatt MN, Chatur YA, Nayak JB (2015). Prevalence of Campylobacter species in milk and milk products their virulence gene profile and antibiogram. Veterinary World 8:1-8.

Newell DG, Fearnley C (2003). Sources of Campylobacter colonization in broiler chickens. Applied and Environmental Microbiology 69:4343-4351.

Njoga EO, Nwankwo IO, Ugwunwarua JC (2019). Epidemiology of thermotolerant Campylobacter infection in poultry in Nsukka agricultural zone Nigeria. International Journal of One Health 5:92-98.

Njoga EO, Onunkwo JI, Okoli CE, Ugwuoke WI, Nwanta JA, Chah KF (2018). Assessment of antimicrobial drug administration and antimicrobial residues in food animals in Enugu State Nigeria Tropical Animal Health and Production 50:897-902.

Nwankwo IO, Faleke OO, Salihu MD, Magaji AA, Musa U, Garba J, Ibitoye EB (2016). Detection and viability of Campylobacter species isolates from different species of poultry and humans from Sokoto State, Nigeria. International Journal of One Health 2:19-23.

Nwankwo IO, Salihu MD, Faleke OO, Magaji AA, Garba J (2018). Seasonal variation in prevalence and antimicrobial resistance of Campylobacter species isolates from the feces of free-range chickens and humans in Sokoto, north western Nigeria. Animal Science Reporter 11:11-21.

Ogie AJ, Salako AE, Emikpe BO, Amosun EA, Adeyemo SA, Akinoluwa PO (2013). The comparative susceptibility of commercial and Nigerian indigenous chicken ecotypes to Salmonella gallinarum infection. Sokoto Journal of Veterinary Sciences 11:49-56.

Okoli CE, Njoga EO, Enem SI, Godwin EE, Nwanta JA, Chah KF (2018). Prevalence toxigenic potential and antimicrobial susceptibility profile of Staphylococcus isolated from ready-to-eat meats. Veterinary World 11:12141221. 
Onunkwo JI, Njoga EO, Njoga UJ, Ezeokafor E, Ekere SO (2018). Brucella seropositivity in chicken and risk factors for Brucella infection at the animal-human interface in Anambra State, Nigeria. International Journal of One Health 4:28-34.

Pourhoseingholi MA, Vahedi M, Rahimzadeh M (2013) Sample size calculation in medical studies. Gastroenterology and Hepatology from Bed to Bench 6:14-17.

Sahin O, Fitzgerald C, Stroika S, Zhao S, Sippy RJ, Kwan P, ... Zhang Q (2012). Molecular evidence for zoonotic transmission of an emergent highly pathogenic Campylobacterjejuni clone in the United States. Journal of Clinical Microbiology 50:680-687.

Sahin O, Yaeger M, Zuowei W, Zhang Q(2017). Campylobacter-associated diseases in animals. Annual Review of Animal Biosciences 5:21-42.

Salihu MD, Junaidu AU, Oboegbulam SI, Egwu GO, Magaji AA, Abubakar MB, Ogbole A (2009). Prevalence of Campylobacter spp in Nigeria indigenous chicken in Sokoto State, Northwestern Nigeria. Internet Journal of Veterinary Medicine 7:1. http://ispubcom/IJVM/7/1/5694

Skarp CPA, Hänninen ML, Rautelin HIK (2016). Campylobacteriosis: the role of poultry meat. Journal of Clinical Microbiology and Infection 22:103-109.

Szczepanska B, Andrzejewska M, Spica D, Klawe JJ (2017). Prevalence and antimicrobial resistance of Campylobacter jejuni and Campylobactercoli isolated from children and environmental sources in urban and suburban areas. BMC Microbiology 17:80. https://doiorg/101186/s12866-017-0991-9

Torralbo A, Borge C, Allepuz A, García-Bocanegra I, Sheppard SK, Perea A, Carbonero A (2014). Prevalence and risk factors of Campylobacter infection in broiler flocks from southern Spain. Preventive Veterinary Medicine 114:106-103.

Ugboma AM, Salihu MD, Magaji AA, Abubakar MB (2013). Prevalence of Campylobacter species in ground water in Sokoto, Sokoto State, Nigeria. Veterinary World 6:285-287.

World Bank (2017). Better life farming - unlocking the potentials of smallholder farmers to reach sustainable development goals. Accessed October 22, 2019 from http:/liveworldbankorg/better-lifefarming?cid=ECR_FB_worldbank_EN_EXTP_SM2018-betterlifefarming_PIX

Yakubu A, Kuje D, Okpeku M (2009). Principal components as measures of size and shape in Nigerian indigenous chickens. Thai Journal of Agricultural Science 42:167-176.
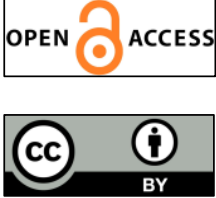

The journal offers free, immediate, and unrestricted access to peer-reviewed research and scholarly work. Users are allowed to read, download, copy, distribute, print, search, or link to the full texts of the articles, or use them for any other lawful purpose, without asking prior permission from the publisher or the author.

License - Articles published in Notulae Scientia Biologicae are Open-Access, distributed under the terms and conditions of the Creative Commons Attribution (CC BY 4.0) License.

(C) Articles by the authors; SHST, Cluj-Napoca, Romania. The journal allows the author(s) to hold the copyright/to retain publishing rights without restriction. 